\title{
TRENDS IN THE APPLICATION OF BIOTECHNOLOGY IN THE FOOD INDUSTRY
}

\author{
U. SAMARAJEEWA \\ Department of Food Science \& Technology, University of Peradeniya, Peradeniya.
}

\section{Introduction}

In biotechnology, biologically derived molecules, structures, cells or organisms are utilized to carry out specific processes. The history of biotechnology dates back to utilization of microorganisms by man to ferment foods. In modern biotechnology attempts are made to program microbial and plant cells to over produce natural substances or to change protein molecules for increased production of flavours, colours and enzymes thereby making new food products available in large quantities. This approach has become necessary to meet the food requirements of an ever increasing population on limited agricultural lands. Thus biotechnology provides many avenues for increasing food production.

\section{Manipulation of Genes}

All cellular processes are controlled by basic biochemical mechanisms which in turn are controlled by the enzymes and other. molecules. The production and activity of enzymes are governed by the genes. At the heart of biotechnology is the ability to design protein molecules having desirable functions by manipulating the genes.

One approach in manipulation of genes is the introduction of genes from various sources into chromosomes of plants, animals and microorganisms thereby generating new characters and activities in cells. This technique is fairly simple in microorganisms, but more complicated in plants as the latter carry a large number of chromosomes. Thus the immediate applications of the biotechnology lies with the microorganisms. The technology has already been developed to increase the production of the enzyme renin which is used in making cheese. Renin for cheese production was traditionally obtained from the calf thymus and was expensive. The gene for calf renin was cloned in to yeast ${ }^{1}$ and fungi. ${ }^{2}$ In the cheese industry, the by product lactose is available in billions of kilograms making its disposal a serious problem in milk producing countries. Naturally occurring yeasts do not carry the enzyme to ferment this sugar. Lactose utilization genes have been cloned into Saccharomyces cerevisiae ${ }^{3}$ and to Xanthomonas campestris. ${ }^{4}$ Cloning has made available a technology to convert the lactose to ethanol, single cell protein or xantham gum. Transfer of genes between species of microorganisms has been attempted to alter the flavour, accelerate fermentation and produce low calorie beer. ${ }^{5}$

Activity of enzymes can be altered by artificially mutating the genes that guide the production of the enzymes. This method could be used to increase the thermal resistance of the enzymes leading to increased efficiency of enzyme catalyzed 
reactions. ${ }^{6}$ "Protein engineering" could also be utilized to confer herbicidal resistance to plants. ${ }^{7}$ The method also may provide mechanisms to increase salt tolerance or iron tolerance in crops allowing them to be cultivated under a wide spectrum of soil conditions.

An understanding of the regulation of ripening enzymes in fruits at a genetic level may help in generation of ripening-delayed cultivars having enhanced shelf life: The genes for the two ripening enzymes polygalacturonase in tomato and cellulase in avocado have already been cloned. 8,9 Deletion of proteins and certain enzymes may confer desirable effects in foods. The degradative enzyme lipoxygenase is responsible for formation of rancid off-flavours in vegetables and vegetable oils. ${ }^{10} \mathrm{~A}$ method to eliminate lipoxygenase may provide a much better quality gingelly oil in our markets.

The West African fruit Thaumatococcus daniellii produces a sweet protein called thaumatin. This compound is 100,000 times sweeter than sucrose and is investigated for its potential as a low calorie sweetener in foods. The gene for thaumatin has been cloned and expressed ${ }^{11}$ and the structure of the protein elucidated. ${ }^{12}$ Thaumatin for the low-calorie food industry may be produced by biotechnological processes.

Genetic engineering could help in improving the nutritional value of foods. ${ }^{13}$ Legumes though rich in proteins are poor sources of sulphur containing amino acids. Similarly methionine is lacking in cereals. Cultivars of legumes and cereals containing more balanced amino acid profiles for humans may be produced through amplification or introduction of the relevant genes. Genetic engineering may help in increasing proteins levels in crops such as rice and maize meeting the protein requirements in many poor countries in the world. Among the vegetable oils coconut is unique in containing a large proportion of eastly digestible short chain and medium chain fatty acids. However, adverse publicity on coconut oil over the presence of a high concentration of saturated fatty acids has restricted its use as a food. Introduction of a desaturation gene to produce unsaturated fatty acids in coconut may increase its nutritional value.

\section{Plant Tissue Culture}

Plant tissue culture provides an excellent means of producing disease-free plants and rapid propagation of food crops for increased productivity. The cell cultures from plants may be used to produce many flavour components derived from plant and microbial cells. Sri Lanka produces spices providing a variety of flavours to foods. Application of cell culture techniques may provide a means of large scale production of spice flavours to the western and local markets. However, it must be recognized that cell culture technology for production of food additives has not developed rapidly as expected. Major constraints appear to be the slow cell division $(20 \mathrm{~h}$ compared to $20 \mathrm{~min}$ in bacteria) and difficulties in extraction of products from the cells as they are not secreted readily into the medium. In spite of these constraints a process to produce shikonin, a colouring material and capsaicin, the hot component in chilli has been developed. ${ }^{14}$ 


\section{Microbial Production of Food Additives}

Potential for the use of microorganisms to bring about complex reactions to produce food additives is high. Many possibilities have already been identified (Table 1). Glutamic acid and Nisin produced in commercial scale by biotechnological processes are already used widely as flavour enhancers and antimicrobial agents respectively in the food industry. Present production of glutamic acid and lysine are in the range of 500,000 and 50,000 MT per year. These two biotechnological processes alone generate around 2 billion US dollars annually. Research is carried out locally for isolation of microorganisms that have a high potential for producing citric acid. While screening of microorganisms from coconut sap, yeasts having characteristic fruity odours and bacteria capable of producing dextrans (rabath) were identified. ${ }^{15,16}$ Screening of locally available microorganisms may provide new biotechnological opportunities for the food industry.

Continuous cultures provide a useful means of selecting microorganisms with complex characters usually associated with several genes. Yeast species from coconut sap have been screened and alcohol tolerance cultivars identified for use in continuous cultures. $^{17}$

\section{Improving Traditional Fermentations}

Traditional fermentation processes operate at several levels of sophistication. Dairy fermentations operate at a level of sophistication much lower than pharmaceutical production; meat and vegetable fermentations are even simpler. In vegetable fermentation little is known of the relevant genetics. Fermentation biochemistry is not fully understood. 'Starter cultures are seldom used. Sri Lanka cultivates and ferments gherkins for export in a big way. The current rate of spoilage of gherkins is very high during fermentation. The industry suffers enormous losses. The factors controlling polygalacturonase activity are not well understood. There is very little local research on enzyme activity and its relationship to spoilages. ${ }^{18}$ There is an urgent need to study fermentation in detail to make gherkin production profitable in Sri Lanka.

\section{Immunoassay}

Ensuring a wholesome food supply free of pathogens and toxins is a priority in the food industry. Immunoassays provide a rapid, simple, sensitive and accurate means of detecting pathogens, toxins, adulterants, contaminants, pesticide residues and hormones in foods. A variety of methods and test kits for immunoassay are available today. $^{20}$ There is an immediate need to develop simple immunoassay techniques to distinguish beef and mutton from other types of animal meat. Methods to detect unpermitted colours and adulterants in local foods, specially the powdered spices, need to be developed based on immunological principles. Development of methods for rapid detection of pesticides in vegetables is also a need. 
Table 1: Some possibilities for microbial production of actual and potential food ingredients. ${ }^{19}$

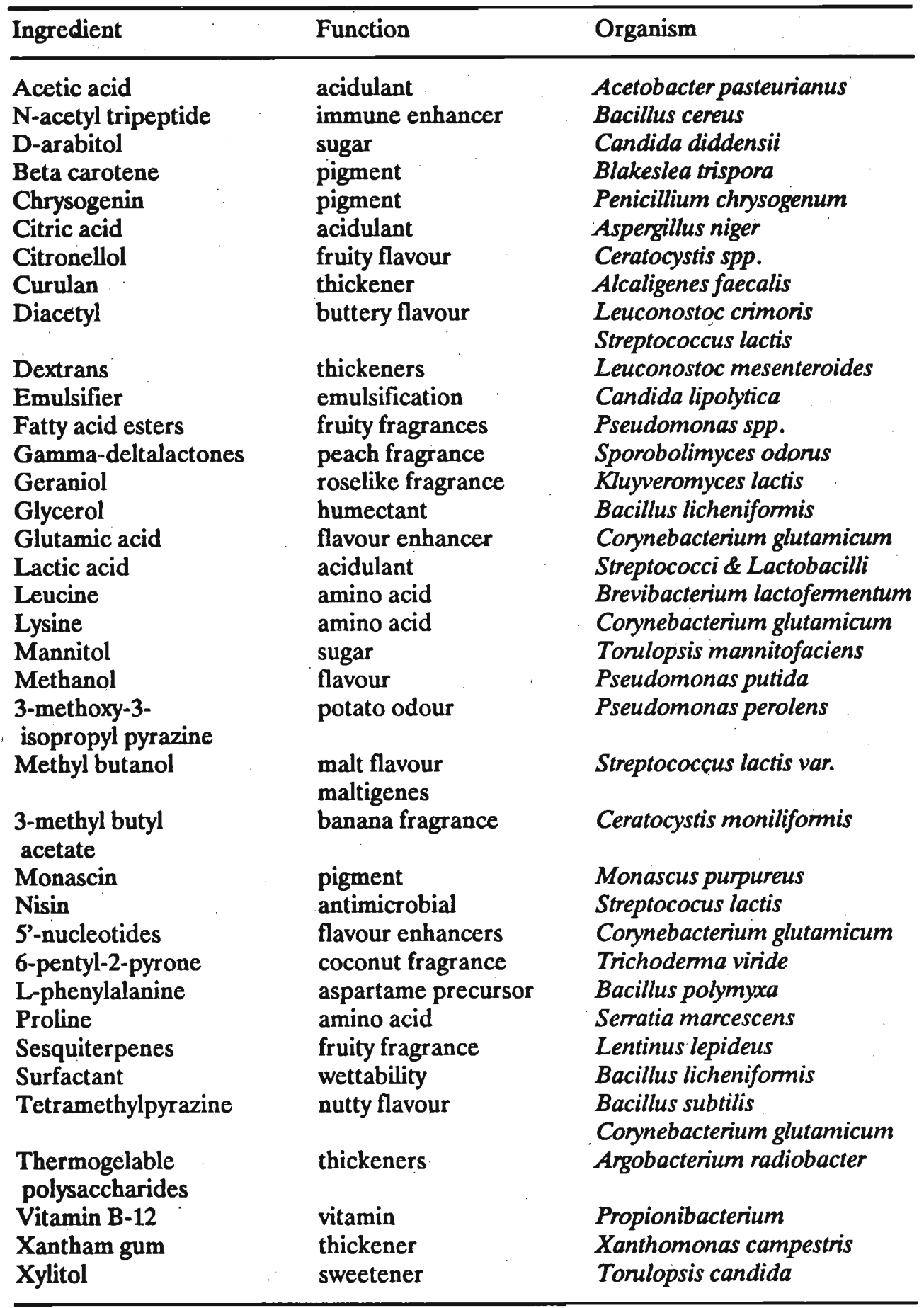




\section{Legislative and Ethical Aspects}

The consumer looks at any new food or an added component in foods with much attention and suspicion. Food legislations look after the safety aspects of the foods to the consumer. Biotechnologically produced foods in a way fall into the category of additives as they may contain new compounds of unknown nutritional effects or enhance the production of compounds at concentrations above naturally present levels. The regulations governing the use of food additives examine the chemical identity, purity and the limitations of the compounds that may be present in foods. As biotechnology may unwittingly admit unknown constituents to foods a question arises as to whether biotechnologically produced foods could be considered "Generally Recognized As Safen. 21 This situation may even result in assertion of regulatory authorities for new market clearances for food of biotechnological origin.

Genes introduced to increase the growth rate or milk production in an animal could be considered similar to a drug or hormone used for the same purpose. In such situations the criteria for the use of drugs in animal husbandry may have to be applied recombinant animals. It is essential to recognize that when top modern technology becomes involved in food production it becomes more and more difficult to convince the public of safety. The food industry faced a bad experience in the 1970's on large scale production of single cell proteins (SCP), which were later discovered to carry potential carcinogens. ${ }^{22}$ In contrast, the enzyme alpha-amylase prepared biotechnologically is accepted for industrial utilization today.

Development of new high yielding food crops or foods through biotechnology may replace export crops from many developing countries affecting their trade balances. ${ }^{13}$ The potential long term effects of genetic modifications of the food supply and the socio-economic and environmental effects of recent advances in food biotechnology are yet to be predicted. ${ }^{23}$

\section{Educational Needs}

The commercial application of biotechnology in the food industry needs a large population of scientists to actively participate in research, production and commercialization. In Japan out of the $\mathbf{1 5 0 0 0}$ agriculture graduates produced annually 2000 specialize in biotechnology related areas. ${ }^{22}$ Sri Lanka is yet to produce graduates of that specialization. It is important that the industry and the educational authorities examine this need early and take action if sustainable biotechnology development plans are to be launched.

\section{Conclusion}

Food biotechnology is a fast evolving field that has the potential to revolutionize world food production. It is essential that we use our resources effectively and develop the knowledge and the infrastructure to make the best use of the available resources in expanding food production through biotechnology. 


\section{References}

1. Moir D. T., Mao J., Duncan J. J., Smith R. A. \& Kohno T. (1985). Production of calf chymosin by the yeast Saccharomyces cerevisiae. Developments in Industrial Microbiology 26: 75 - 81 .

2. Cullen D., Gray G. L., Wilson L. J., Hayenga K. J., Lamsa M. H., Rey. M. W., Norton S. \& Berka R. M. (1987). Controlled expression and secretion of bovine chymosin in Aspergillus nidulans. Biotechnology 5: 369 - 374.

3. Sreekrishna K. \& Dickson R. C. (1985). Construction of strains of Saccharomyces cerevisiae that grow on lactose. Proceedings of the National Academy of Sciences, USA 82: 7909-7913.

4. Walsh P. M., Haas, M. J. \& Somkuti G. M. (1984). Genetic construction of lactose utilizing Xanthomonas campestris. Applied and Environmental Microbiology 47: 253- 255.

5. Panchal C. J., Russell I., Sills A. M., \& Stewart G. G. (1984). Genetic manipulation of brewing and related yeast strains. Food Technology 38 (2): 99 -104.

6. Wetzel R. (1986). Protein engineering: potential applications in food processing. In: Biotechnology in Food Processing (Eds. Harlander S. K. and Labusa T. P.) Noyes Publications, Park Ridge, New Jersey, USA.

7. Chaleff R. S. \& Ray T. B. (1984). Herbicide resistant mutants from tobacco cell cultures. Science 223: 1148- 1151.

8. Christofferson R. E., Tucker M. L., \& Laties G. G. (1984.) Cellulose gene expression in ripening avocado fruit: the accumulation of cellulase mRNA and proteins as demonstrated by cDNA hybridization and immunodetection. Plant Molecular Biology 3: 385 - 391.

9. Della-Penna D., Alexander D. C. \& Bennett A. B. (1986). Molecular cloning of tomato polygalacturonase: analysis of polygalacturonase mRNA levels during ripening. Proceedings of the National Academy of Sciences, USA 83: 6420-6424.

10. Moshy R. (1986). Biotechnology: its potential impact on traditional food processing. In Biotechnology in Food Processing. (Eds. Harlander S. K. and Labusa T. P.) Noyes Publications, Park Ridge, New Jersey, USA.

11. Ledeboer A. M., Veripps C. T. \& Dekker B. M. M. (1984). Cloning the natural gene from the sweet tasting plant protein thaumatin. Gene 30: $23-28$.

12. De Vos A. M., Hatada M., Van der Wel H., Drabbendam H., Peerdeman A. F. \& Kim, S. H. (1985). Three dimensional structure of thaumatin I, an intensely sweet protein. Proceedings of the National Academy of Sciences, USA 82: 1406-1409. 
13. Junne G. (1991). Biotechnology: the impact on food and nutrition in developing countries. Food Nutrition and Agriculture 1 (1): 32 - 36.

14. Tombs M. P. (1990). Biotechnology in the Food Industry First edition. Open University Press, Milton Keynes; pp. 143 - 146.

15. Samarajeewa U., Dissanayake M. \& Wijeratna M. C. P. (1977). Some observations on composition and formation of "Rabath". Proceedings of the Sri Lanka Association for the Advancement of Science 33: 52.

16. Athputharajah J. D., Vidanapathirana G. \& Samarajeewa U. (1986). Microbiology and biochemistry of natural fermentation of coconut palm sap. Food Microbiology 3: $273-280$.

17. Wijesinghe D. G. N. G. \& Samarajeewa U. (1988). Screening yeasts from coconut inflorescence sap for continuous alcoholic fermentation. Food Microbiology 5: $119-123$.

18. Zoysa R. S. de., Pathirage A. C. \& Samarajeewa U. (1993). Pectinolytic enzyme activity in fermenting gherkins. Proceedings of the Sri Lanka Association for the Advancement of Science 49: (accepted for presentation)

19. Wasserman B.P., Montville T. J. \& Korwek E. L. (1988). Food Biotechnology. Food Technology 42 (1): 133 - 147.

20. Samarajeewa U., Wei C. I., Huang T. S. \& Marshall M. R. (1991). Application of immunoassay in the food industry. CRC Critical Reviews in Food Science and Nutrition 29: (6) 403 - 434.

21. Korwek E. L. (1990.) Food biotechnology regulations. Food Technology 44 (3): $76-80$.

22. Hayashi T. (1986). Biotechnology merges into Japanese food industry. Food Technology 40 (11): $67-69$.

23. .Harlander S. K. (1991). Social, moral and ethical issues in food biotechnology. Food Technology $45(5)$ : 152 - 161. 